\title{
PRAKTYKI OPORU WSPÓtCZESNEGO TEATRU ALTERNATYWNEGO NA PRZYKŁADZIE DZIAŁAŃ ARTYSTYCZNYCH I POZATEATRALNYCH FUNDACJI BARAK KULTURY
}

Practices of resistance of the contemporary alternative theater on an example of artistic and paratheatrical actions of the Barak Kultury Foundation

\begin{abstract}
The article deals with the problem of resistance practices used by artists and animators of the contemporary scene of independent theaters, with particular emphasis on the activities of the Barak Kultury Foundation in Poznan, in which the Ba-Ku Theater functions. These contemporary practices of contention include broad artistic and extra-theatrical activities, which are an expression of rebellion, against important social issues such as the problem of ethnic minorities, sexual and disabled people, pollution and environmental degradation, excessive consumerism.
\end{abstract}

Keywords: alternative theater, socially engaged theater, non-theater activities, civic and emancipation movements, resistance practices

Poniższy artykuł będzie dotyczył problemu praktyk oporu stosowanych przez twórców i animatorów współczesnej sceny teatrów niezależnych, ze szczególnym uwzględnieniem działań poznańskiej Fundacji Barak Kultury, w ramach której funkcjonuje Teatr Ba-Ku.

W pierwszej kolejności chciałabym wytłumaczyć, dlaczego sięgnęłam w tytule artykułu po termin „teatr alternatywny”, który wśród badaczy, krytyków i twórców tego nurtu budzi największe wątpliwości, szczególnie w odniesieniu do zespołów i ich kulturotwórczych inicjatyw działających po 1989 roku. Przed przełomem ustro- 
jowym 1989 roku nazwa „teatr alternatywny” była stosowana chętnie i powszechnie, jako że znaczenie i funkcje tegoż teatru były nieco odmienne w okresie Polski komunistycznej. Teatr ten był definiowany jako „alternatywny”, ponieważ „wyrósł on z opozycji wobec teatru instytucjonalnego, jako jego alternatywa organizacyjna, programowa i artystyczna"2. Opozycyjność teatru alternatywnego wobec teatru dramatyczno-repertuarowego podkreśla wielu jego komentatorów, w tym również Tomasz Kubikowski, który stwierdza: „(...) gest odłączenia się od «głównego nurtu» w imię pewnych wartości i wynikłą z tego gestu odrębność instytucjonalną należy uznać za niezbędny (...) i podstawowy wyróżnik tego teatru"’.

Współczesny teatr alternatywny, nazywany chętniej niezależnym lub offowym, przestał być opozycyjny wobec teatru dramatyczno-repertuarowego. Pisałam - w innym tekście - o tym następująco: „Nastąpiło zbliżenie dwóch niegdyś opozycyjnych modeli teatru - niezależnego i instytucjonalnego. Teatr instytucjonalny zaabsorbował: twórców działających na obszarze teatru niezależnego (...) metody pracy charakterystyczne dla teatru alternatywnego (pisanie na scenie, kreacja zbiorowa, improwizacja), estetyczne poszukiwania, eksperymenty stylistyczne, tematykę, poniekąd widza, a z całą pewnością refleksję teoretyczną i część krytyki. Wyraźna opozycja, jaka pozostała, to sposób finansowania (...)"’4. Z moimi wnioskami zgadza się wielu badaczy zarówno teatru alternatywnego, jak i instytucjonalnego, a także sami niezależni twórcy. Magdalena Gołaczyńska odnotowała:

Należy (...) podkreślić, że granice między teatrem niezależnym wywodzącym się z alternatywy a teatrem instytucjonalnym bardzo się ostatnio zatarły. Widać to na przykładzie podobnych zainteresowań tematycznych, takich jak aktualna problematyka społeczna czy eksponowanie (...) lokalnej historii. Teatr niezależny przestał więc odgrywać rolę alternatywy estetycznej czy ideowej. Twórcy nie buntują się przeciw teatrowi czerwonych, pluszowych foteli ani też jego hierarchii organizacyjnej, co najwyżej ignorują działalność instytucji teatralnych, koncentrując się na własnych projektach. Teatr niezależny nie jest już awangardą na poziomie obyczajowym (...). Nie ma też wyraźnych rozgraniczeń dotyczących składu zespołów - aktorzy występują zarówno w teatrach niezależnych, jak i miejskich $(\ldots)^{5}$.

Ze stanowiskiem badaczki zgadza się Adam Ziajski, twórca poznańskiego Centrum Rezydencji Teatralnej Scena Robocza: „(...) obszary teatru instytucjonalnego

1 Nazwa ,teatr alternatywny” pojawiła się po ukazaniu się książki Aldony Jawłowskiej Drogi kontrkultury (zob. A. Jawłowska, Drogi kontrkultury, Państwowy Instytut Wydawniczy, Warszawa 1975). Określenia zaczęto używać na przełomie lat 70. i 80., a w latach 90. nazwa uzyskała dominującą pozycję.

2 M. Semil, E. Wysińska, Stownik wspótczesnego teatru, Wydawnictwa Artystyczne i Filmowe, Warszawa 1980, s. 338-339.

3 T. Kubikowski, Teatr alternatywny, w: M. Fik (red.), Encyklopedia kultury polskiej XX wieku. Teatrwidowisko, Instytut Kultury Polskiej, Warszawa 2000, s. 227.

4 M. Grenda, Mistrzowie drugiego planu. Poznański teatr alternatywny po 1989 roku, Wydawnictwo Naukowe WNS UAM, Poznań 2013, s. 8-9.

5 M. Gołaczyńska, Wrocławski teatr niezależny, Wydawnictwo Uniwersytetu Wrocławskiego, Wrocław 2007, s. 10 . 
i niezależnego tak ściśle się pokrywają, że trudno je odseparować, one po prostu przeplotły się, i to w obu kierunkach. Nie ma jasnego podziału ani merytorycznego, jak i formalnego"6.

Teatr alternatywny wyrosły ze studenckiego ruchu teatralno-społecznego zrodził się jednak nie tylko $\mathrm{z}$ negacji teatru instytucjonalnego, ale także $\mathrm{z}$ negacji rzeczywistości społecznej i politycznej okresu PRL-u, z potrzeby antysystemowego buntu i kontestacji panujących konwencji i stosunków, w konkretnej zastanej rzeczywistości, jaką był okres „realnego socjalizmu”" Po upadku komunizmu powstało zatem pytanie: czy teatr konstytuujący swą tożsamość na podstawie wieloaspektowej opozycyjności wobec konkretnego systemu społeczno-politycznego, tworzony przez pokolenie '68, stracił rację bytu? Jak zdoła utrzymać ciągłość tradycji sceny niezależnej w wolnej Polsce, bez cenzury i obowiązku bycia „sumieniem narodu”? Przeciwko czemu i komu ma się buntować w kraju, w którym w wyniku demokratycznych wyborów ustanowiono wybraną przez wolne społeczeństwo władzę?

Tu dochodzę do zasadniczej tematyki mojego artykułu, jaką jest opis praktyk oporu na obszarze współczesnego teatru alternatywnego. Z pewnością bowiem można stwierdzić, że teatr ten, choć uległ licznym zmianom na gruncie estetyki, etyki czy sposobów jego organizacji i finansowania, pozostał teatrem, dla którego opór jest nadal częścią tożsamości. Osłabła w jego twórcach postawa kontestacji i buntu wobec rzeczywistości politycznej, ale na sile zyskał protest, który uległ pacyfikacji i odpolitycznieniu i przybrał formę szerokiego zaangażowania się w kwestie społeczne. Marta Strzałko z Teatru Biuro Podróży komentuje: „(...) teatr alternatywny nie zabiega już tak bardzo o rolę i powinność naprawy rzeczywistości politycznej, jak robił to ruch teatru alternatywnego w komunistycznej Polsce"8. Mówiąc krótko, dzisiejszy teatr alternatywny nie dąży do radykalnej reformy istniejącego ustroju (tak jak robił lub chciał to robić w minionych dekadach), nie zajmuje wyraźnej i jednoznacznej pozycji wobec polityki państwa, nie traktuje teatru jako aparatu walki i oporu, ale jako miejsce tworzenia alternatywnych sposobów społecznego myślenia, reagowania i działania. Twórcy i animatorzy współczesnej sceny teatrów alternatywnych angażują się w kwestie społeczne, włączają się w społeczną debatę na najbardziej palące lub kontrowersyjne tematy za pomocą różnych spacyfikowanych praktyk (ich protest nie zawsze oznacza opozycję i walkę ,wprost”), do których zaliczam zarówno działalność artystyczną, jak i pozateatralną. Cechuje ich postawa twórcza, a nie postulatywna, wzorowana kiedyś na żądaniach kontrkultury9 ${ }^{9}$, budowanie alter-

\footnotetext{
M. Grenda, Mistrzowie drugiego planu ..., s. 9.

Stąd określany był również jako teatr „kontestacji”, „kontrkultury”, ,polityczny”, „,wolny”, ,walczący".

8 Rozmowa z Teatrem Biuro Podróży, w: M. Grenda, Mistrzowie drugiego planu ..., s. 21.

9 O kontrkulturze Aldona Jawłowska i Zofia Dworakowska pisały następująco: „,...) rozwijający się w latach sześćdziesiątych ruch, zmierzający do radykalnej zmiany w obszarze szeroko rozumianej kultury. A więc zarówno w sferze idei i wartości naczelnych, konstytutywnych dla zastanego systemu społecznego, oraz w sferze obyczajów i stylu życia, jak i we wszystkich formach kulturowej ekspresji
} 
natywnych elementów zastanej rzeczywistości, a nie jej burzenie ${ }^{10}$. Pytani o kwestię protestu, buntu, oporu, odpowiadają w podobnym tonie - Hubert Kożuchowski (Teatr Koinspiracja): „Mój bunt objawia się pracą organiczną. Nie robię rozpierdolu wokół siebie, a raczej próbuję organizować miejsce, w którym żyję" "11; Aleksandra Knaś (absolwentka Akademii Teatru Alternatywnego): „Wychodzę na ulicę i śpiewam, bo czuję, że jest to pewna forma wyrażania wolności"12. Marcin Głowiński (Teatr Circus Ferus): „Mógłbym użyć terminu «niezgoda», ale «bunt» rezerwuję dla bardziej zdecydowanych gestów osadzonych w innym kontekście"13; Przemysław Prasnowski (Fundacja Barak Kultury, Teatr Ba-Ku): „Nie wiem czy można to nazwać buntowaniem, ale zawsze staraliśmy się być wierni wartościom, które można osadzić w pewnych nurtach kontrkultury. Myślę, że bliższy jest nam ten nurt, który oprotestowuje rzeczywistość poprzez śmiech. (...) jeśli przeciw czemuś się buntujemy, to przeciwko wszelkim przejawom dyskryminacji, wywyższania się i lekceważenia odmienności"14.

Trzeba jednak przypomnieć, że na gruncie polskiego teatru alternatywnego funkcjonującego przed przełomem ustrojowym 1989 roku istniały „dwie formy sprzeciwu wobec kultury dominującej, z jednej strony - aktywnej krytyki, buntu, a z drugiej odmowy uczestnictwa i wycofania się poza jej obręb" ${ }^{15}$. Postawa twórcza i życiowa reprezentantów współczesnej sceny teatrów alternatywnych lokuje się gdzieś pośrodku. Przedstawiciele obecnej sceny teatrów niezależnych świadomie zrezygnowali $\mathrm{z}$ bezpośredniego angażowania się $\mathrm{w}$ kwestie polityczne na rzecz zainteresowania się innymi formami uczestnictwa w życiu społecznym. ,Wymienić «antypaństwowy» na «społecznie wrażliwy»" loletni obserwator polskiej sceny niezależnej. Chciałabym w tym miejscu przyjrzeć się owym działaniom i strategiom czyniącym z współczesnego offu teatr ,społecznie wrażliwy" i omówić działalność artystyczną i pozateatralną poznańskiej Fundacji Barak Kultury ${ }^{17}$.

jak muzyka, literatura czy sztuka”. Zob. A. Jawłowska, Z. Dworakowska, Wolność w systemie zniewolenia. Rozmowy o polskiej kontrkulturze, Instytut Stosowanych Nauk Społecznych UW, Warszawa 2008, s. 8.

10 Na ten temat również piszę w książce: M. Grenda, Poznańscy Offeusze. Teatr alternatywny Poznania po 1989 roku jako zjawisko artystyczne, spoleczne i kulturotwórcze, Wydawnictwo Naukowe WNS UAM, Poznań 2018.

11 J. Lizurek, Przeczuwać bunt, „Nietak!t” 2016, nr 1 (24), s. 68.

12 Ibidem, s. 69.

13 M. Grenda, Mistrzowie drugiego planu..., s. 124.

14 Rozmowa z Przemysławem Prasnowskim, założycielem Fundacji Barak Kultury, zob. Aneks.

15 Z. Dworakowska, Kontrkulturowe wyjścia z teatru, w: A. Jawłowska, Z. Dworakowska (red.), Wolność w systemie zniewolenia..., s. 157.

16 M. Grudzińska, Ł. Drewniak, Obywatel Teatr, w: Krakowskie Reminiscencje Teatralne. Trzy dekady teatru, Stowarzyszenie Rotunda, Kraków 2004, s. 15.

17 W artykule koncentruję się na działalności Fundacji Barak Kultury, jednak w obszarze współczesnego teatru alternatywnego funkcjonuje wiele grup i ośrodków, którym przyświecają podobne cele 
Fundacja Barak Kultury (dalej będę stosować skrót: Barak Kultury lub BK) powstała z inicjatywy ekswspółzałożyciela Teatru Strefa Ciszy - Przemysława Prasnowskiego - oraz osób związanych z poznańskim kulturoznawstwem Wydziału Nauk Społecznych UAM. Inicjatywa ${ }^{18}$ początkowo przybrała formę spontanicznych spotkań odbywających się w byłej siedzibie Teatru Strefa Ciszy - drewnianym baraku zlokalizowanym przy ulicy Grunwaldzkiej 55 w Poznaniu, od którego wzięło nazwę całe przedsięwzięcie. Przestrzeń ta była nie bez znaczenia, ponieważ jej bezpretensjonalność sprzyjała naturalności spotkań, spontaniczności kontaktów, przełamywaniu barier. Barak Kultury od samego początku stawiał na różnorodność, dialog i tolerancję - zapraszał do siebie ludzi o różnym lub nawet skrajnym światopoglądzie, wykształceniu czy statusie społecznym i ekonomicznym. Od samego początku wizja i misja Baraku Kultury były kształtowane w odniesieniu do dwóch kategorii: „polifonii” i pojęcia „inności/Innego”. Sam pomysłodawca wyjaśnia:

Polifoniczność oznacza (...) otwarcie się na inność, kategorię, która coraz bardziej nas interesuje i która pojawia się w wielu naszych projektach (...). Polifonia (...) przekłada się na nasze działania, które są różnorodne. Przygotowujemy równolegle projekty społeczne, edukacyjne, artystyczne, kulturalne. Nie mamy z góry utartych założeń, schematów, których chcemy się trzymać. Myślę, że w tym tkwi największa siła Baraku Kultury. (...) Wachlarz naszych propozycji jest ogromny. Skupiamy wokół siebie różne środowiska, działamy ponad podziałami klasowymi, ekonomicznymi, kulturalnymi, społecznymi. Odbiorcą naszych działań są ludzie w różnym wieku, o różnych profesjach, upodobaniach, wartościach. Do tworzenia projektów zapraszamy zarówno artystów, jak i naukowców, anarchistów, feministki, społeczników. Myślę jednak, że naszych gości, jak i odbiorców łączy ciekawość świata, otwartość, pokora, chęć poszerzania wiedzy i własnych horyzontów ${ }^{19}$.

Animatorów inicjatywy, a także osób związanych z Barakiem Kultury łączy również misja społeczna i niezgoda na zastane mechanizmy społeczne. Działalność fundacji materializowana w jej konkretnych i różnorodnych projektach wpisuje się w globalne ruchy emancypacyjne. Barak Kultury i działający przy nim Teatr Ba-Ku to oddolna inicjatywa prospołeczna, która za misję stawia sobie przede wszystkim wspieranie grup dyskryminowanych, izolowanych lub zagrożonych mechanizmami stygmatyzującymi, takich jak mniejszości etniczne, seksualne czy osoby z niepełnosprawnością. Promuje postawy liberalne i tolerancyjne; wspiera budowanie społeczeństwa obywatelskiego opartego na takich wartościach jak solidarność, równość, wspólnota, poszanowanie, dialog; walczy z dyskryminacją, stereotypizacją, nierównością. To organizacja działająca na różnorodnych polach: sztuki, terapii, edukacji czy ekologii, które w dalszej części tekstu chciałabym przytoczyć i opisać. Zacznę od wybranych spektakli - tych zaangażowanych społecznie - przygotowanych przez zespół Teatru Ba-Ku.

i założenia. Są to np. Teatr Brama z Goleniowa, Ośrodek Teatralny Kana ze Szczecina, Centrum Rezydencji Teatralnej Scena Robocza z Poznania, Teatr Chorea z Łodzi i wiele innych.

18 Barak Kultury powstał w 2005 roku, od 2008 roku działa jako fundacja.

19 M. Grenda, Rozmowa z Teatrem Strefa Ciszy, w: eadem, Mistrzowie drugiego planu..., s. 83-84. 
Teatr Ba-Ku, powstały w 2009 roku, współtworzą w dużej mierze osoby wywodzące się ze środowisk mniejszościowych: imigranci, homoseksualiści, anarchiści, ekolodzy, niepełnosprawni lub osoby współpracujące z grupami wykluczonymi: terapeuci, nauczyciele. „Justyna Tomczak-Boczko, mama dziecka z niepełnosprawnością, działa na rzecz osób z dysfunkcjami. Bartosz Żurawiecki, pisarz i krytyk sztuki, związany jest ze środowiskiem LGBT. Aktorzy: Hiszpanka Eva Rufo i Francuz z arabskimi korzeniami Hacen Sahraoui reprezentują mniejszości etniczne i kulturowe, natomiast Małgorzata Walas-Antoniello współtworzyła teatr dla osób uzależnionych o nazwie Wiem, kiedy nie mogę. Przemysław Prasnowski, główny reżyser spektakli Teatru $\mathrm{Ba}-\mathrm{Ku}$, koncentruje się przede wszystkim na zagadnieniu «Innego»" ${ }^{20}$. W kontekście poruszanej problematyki tegoż artykułu warto omówić te spektakle, które stanowią wyraz niezgody, protestu, oporu ich twórców oraz realizują misję i założenia prospołeczne fundacji.

Spektakl plenerowy Szrot Reaktywacja, mający swą premierę w 2014 roku, był wyrazem sprzeciwu wobec polityki nadmiernego konsumpcjonizmu i związanym z nim problemem postępującego zanieczyszczenia środowiska. Sami twórcy o swoim spektaklu, odbywającym się na uteatralizowanym wysypisku śmieci, napisali:

Spektakl plenerowy Szrot Reaktywacja opowiada o ludziach wyrzuconych na margines cywilizacji. Żyjących w zamkniętym świecie zużytych przedmiotów, przetwarzających to, co inni skonsumowali. Zatruwani spalinami przez posiadających władzę oprawców, odnajdują w sobie pragnienie wolności i buntu. Szrot Reaktywacja wykorzystuje nowoczesną formę sztuki, jaką jest recycling art - przetwarzania i przywracania znaczenia przedmiotom. Nowe, ekologiczne życie przedmiotów jest w spektaklu szansą do rozpoczęcia nowego życia przez zniewolonych spalinami szrotowców ${ }^{21}$.

Spektakl Teatru Ba-Ku wpisał się w ideologię globalnych ruchów ekologicznych i antykonsumpcyjnych. W filozofię praktyk zero waste, no waste, reuse i repair czy ruch Do It Yourself (DIY), promujących minimalizację wytwarzanych odpadów, a także ponowne i maksymalne zużycie przedmiotów traktowanych jak śmieci, w myśl hasła „Nie wyrzucaj, tylko przerabiaj”.

Kolejnym przedsięwzięciem teatralnym poruszającym ważne kwestie społeczne i trudne kulturowe tematy był spektakl Ćma, zaprezentowany w 2012 roku. Scenariusz do tego kameralnego monodramu powstał na kanwie barwnej biografii Kazimiery Iłłakowiczówny, poznańskiej poetki, niezależnej, ekscentrycznej kobiety, oślepłej na starość i skazanej na pomoc obcych jej osób. Spektakl traktował o problemie samotności, niedołężności, chorobie, wykluczeniu osób starszych i stygmatyzacji, która w konsekwencji prowadzi do dyskryminacji. Twórcy Teatru Ba-Ku skupili się na tematach pomijanych przez kulturę masową i popularną, a coraz bardziej dotykających szybko starzejące się społeczeństwa. Ich artystyczna wypowiedź była formą

20 M. Grenda, Poznańscy Offeusze..., s. 227-228.

21 Szrot Reaktywacja - Teatr Ba-Q, http://barakkultury.pl/szrot-teatr-ba-q/ (dostęp: 23.05.2019). 
oporu przeciwko społeczeństwu nastawionemu na gospodarkę rynkową, w której osoby starsze, nieaktywne zawodowo - jako te nieprzydane - są wykluczane.

$\mathrm{Z}$ równie trudnym zagadnieniem zmierzyła się kolejna produkcja Teatru Ba-Ku utrzymana w charakterze one man show - zatytułowana Całe życie w dresach (2016). To opowieść o życiu zdeterminowanym przez ciężką chorobę dziecka. Spektakl, zagrany brawurowo przez Justynę Tomczak-Boczko, choć utrzymany w persyflażowym charakterze, zmaga się z bardzo złożonym społecznie tematem, jakim jest wychowywanie niepełnosprawnych dzieci i trudną sytuacją ich opiekunów, którzy nierzadko stają się obiektem kpin czy napiętnowania społecznego, nie mówiąc o ich często krytycznej sytuacji materialnej i bytowej, bagatelizowanej przez polskie państwo.

Kolejnym spektaklem będącym wyrazem oporu i niezgody na wykluczenie i stygmatyzację grup mniejszościowych było przedsięwzięcie zatytułowane Rezerwat (2016). „Tytułowy rezerwat składał się z panoptykonu osobliwych przedstawicieli środowisk gejowskich, anarchistycznych czy etnicznych, m.in. Araba, charakternej Hiszpanki, dwóch homoseksualistów czy punkowca-anarchisty. Nad całością tej barwnej i krnąbrnej «zbieraniny» głoszącej swoisty manifest mniejszości czuwał"22 „«barbarzyńca z wyboru» Przemek Prasnowski, tym razem w roli Myśliwego polującego na gatunki «gorszego sortu»"23. Spektakl, oparty na strategiach subwersywnych, do których zaliczam ironię i pastisz, bez moralizatorstwa i uprawiania taniej pedagogiki prowokował do dyskusji na temat obecnej sytuacji środowisk mniejszościowych: religijnych, seksualnych, etnicznych, ideologicznych, i bezceremonialnie demaskował przywary „prawdziwego” Polaka. Zespołowi Przemysława Prasnowskiego udało się odnieść krytycznie do problemu narastającego w naszym kraju rasizmu i wzrastającej liczbie przestępstw na tym tle.

Powyżej wymieniłam spektakle Teatru Ba-Ku, które są ucieleśnieniem sprzeciwu jego twórców wobec aktualnych problemów społecznych. Spektakle te są wyrazem krytycznej postawy i oporu wobec zastanej rzeczywistości i kwestii dla niej symptomatycznych. Artyści w swoich przedsięwzięciach, stawiając niewygodne pytania, prowokują widza do dyskusji, a przynajmniej do pogłębionej i krytycznej refleksji nad otaczającym go światem.

Trzeba jednak zaakcentować, iż teatr alternatywny od samego początku swego istnienia był obszarem, który równolegle rozwijał się jako nurt twórczości artystycznej oraz ruch społeczny. Współczesna scena niezależna również nie ogranicza się tylko do tworzenia i wystawiania spektakli, ale wyznacza sobie znacznie poważniejsze cele, czego namacalnym przykładem są działania pozateatralne Fundacji Barak Kultury. Pora zatem wymienić i pokrótce opisać najważniejsze projekty BK z zakresu edukacji, terapii czy animacji społeczno-kulturalnej, które - według mnie - należą do praktyk oporu współczesnego teatru alternatywnego.

22 M. Grenda, Poznańscy Offeusze..., s. 228.

23 Antykabaret Barbarzyńcy PL ,Rezerwat”, http://barakkultury.pl/antykabaret-barbarzyncy-pl/ (dostęp: 25.05.2019). 
Zacznę od projektów, które nie są już realizowane. Pierwszym z nich będą $W y$ kłady polifoniczne, od których rozpoczął swą działalność BK. Wykłady polifoniczne odbywały się cyklicznie od 2005 do 2010 roku. Ich głównym założeniem była konfrontacja osób z różnych środowisk, o różnych lub skrajnych światopoglądach, pasjach, wyznaniach, profesji. „Założeniem Wykładów polifonicznych jest wzajemne przenikanie się wątków, polemicznych opinii i różnych form wypowiedzi, które zebrane razem tworzą wielogłosową całość”24 - thumaczyli cel i misję tych spotkań założyciele Baraku Kultury. Otwarta i popularnonaukowa formuła spotkań miała wytwarzać w słuchaczach „polifoniczną percepcję” przez uczestnictwo w dyskusji wokół danego, konkretnego tematu, omawianego z różnych, często bardzo skrajnych perspektyw, co pozwalało na „wyrobienie” sobie własnej, przez nikogo niezmanipulowanej opinii. Tematyka Wykładów polifonicznych dotykała z rzadka omawianych, pomijanych lub trywializowanych zagadnień, takich jak śmierć, wykluczenie społeczne czy miłość, bądź skupiała się na kontrowersyjnych osobowościach (Dario Fo, Karol Marks, Stanisław Witkiewicz, Władysław Strzemiński, Stanisław Lem), których życiorysy, postawa lub wybory były zaczynem do szerszych dyskusji. Wykładom towarzyszyły wydarzenia artystyczne - pokazy filmów, happeningi, koncerty które przyciągały różne grupy społeczne, etniczne, wiekowe.

Równie ciekawym projektem były Poznańskie Dni Kultury Prawosławnej (20062012). Wydarzenie miało przede wszystkim zwrócić uwagę na istniejącą, aczkolwiek marginalizowaną i słabo znaną, kulturę prawosławia, w szczególności na terenie Wielkopolski, a także otworzyć dyskusję na temat sytuacji mniejszości wyznaniowych w Polsce, wokół których nierzadko narastają mity, nieporozumienia, społeczny ostracyzm. Jak podkreślali animatorzy wydarzenia: „Celem spotkań jest dialog mający za zadanie zrozumienie zróżnicowanej kulturowo i religijnie rzeczywistości”25. Poznańskim Dniom Kultury Prawosławnej współtowarzyszyły koncerty, wystawy, prelekcje, pokazy filmów czy warsztaty pisania ikon.

Tematyki feminizmu, równouprawnienia, kwestii płci kulturowej dotyczył natomiast projekt zatytułowany Salon w Różach, odbywający się od 2009-2010 roku. Wydarzenie prezentowało „sylwetki charyzmatycznych kobiet, które wywarły istotny wpływ na historię kultury, oraz takich, których prywatne losy przybrały postać intrygujących opowieści”26. Salon w Różach współtworzyły zaproszone do dyskusji pisarki, anarchistki, aktywistki, badaczki, a także liczne audytorium złożone nie tylko z kobiet.

Dwa najważniejsze i do tej pory realizowane projekty przez Baraku Kultury to festiwale. Pierwszym z nich jest Festiwal Inwazja Barbarzyńców, którego pierwsza edycja odbyła się w 2011 roku. Bogaty, różnorodny i interdyscyplinarny program imprezy tworzą różne wydarzenia: spektakle, koncerty, flash moby, happeningi, panele,

\footnotetext{
24 Zob. http://barakkultury.pl/wyklady-polifoniczne-2005-2010/ (dostęp: 26.05.2019).

25 Zob. http://barakkultury.pl/poznanskie-dni-kultury-prawoslawnej-2006-2012/ (dostęp: 27.05.2019).

26 Zob. http://barakkultury.pl/tag/salon-w-rozach-2009-2010/ (dostęp: 27.05.2019).
} 
wykłady, ale także wydarzenia edukacyjne i warsztaty, na przykład języka migowego czy recyklingu. Główną ideą festiwalu jest zaprezentowanie twórczości, aktywności osób - tytułowych „barbarzyńców” - które działają w alternatywnym obiegu kultury: anarchistów, outsiderów, ekologów, wegetarian, wegan czy feministek. Impreza z kolei jest przygotowywana z myślą o grupach mniejszościowych: etnicznych, wyznaniowych, ale także osób z niepełnosprawnością czy seniorów.

Tym grupom poświęcony jest Inny Festiwal, zainicjowany w 2013 roku pod hasłem „Mniejszość jest dla nas ciekawsza niż większość”. Jego głównym celem jest inkluzja społeczna, wyrównywanie szans, zapewnienie równego dostępu do kultury oraz prawa do jej współtworzenia. Kolejnym zadaniem cyklicznie odbywającej się imprezy jest integracja osób niepełnosprawnych z pełnosprawnymi, aktywizacja całego środowiska związanego z zagadnieniem niepełnosprawności: chorych oraz ich opiekunów, terapeutów, psychologów, nauczycieli. Inny Festiwal porusza podczas licznych wykładów, prelekcji, spotkań tematy tabu, takie jak życie seksualne czy zawodowe osób z dysfunkcjami, frustracja osób opiekujących się nimi i wiele innych. Dlatego jego wydarzenia adresowane są zarówno do osób niepełnosprawnych, jak i pełnosprawnych. Są to na przykład warsztaty psychoterapeutyczne dla opiekunów, kursy dla przewodników osób niewidzących czy warsztaty z języka migowego. Festiwal jednocześnie promuje sztukę tworzoną przez osoby chore, czyniąc z nich pełnoprawnych artystów. Wszystkie wydarzenia składające się na imprezę są tworzone w miejscach dostosowanych dla osób z niepełnosprawnością, prezentowane $\mathrm{z}$ audiodeskrypcją lub tłumaczone na język migowy.

Fundacja Barak Kultury oferuje również bogaty program edukacyjny, który koncentruje się wokół trzech nadrzędnych tematów: kulturowości, niepełnosprawności i ekologii.

Znaki szczególne i Niebieska parasolka, zrealizowane w 2016 roku, adresowane były do dzieci w wieku szkolnym i licealistów, a także ich nauczycieli. Obydwa projekty przybrały formę interaktywnych warsztatów, dyskusji, których celem było tworzenie postawy obywatelskiej związanej z pojęciem wielokulturowości. Rozmowy, spotkania i liczne działania dotyczyły kwestii kształtowania się tożsamości, naszego pochodzenia i jego wpływu na życie jednostki. Młodzież próbowała odpowiedzieć na pytanie, czym jest dla nich wielokulturowość, jakie wiążą się z nią pytania, wątpliwości, ale również szanse i wyzwania.

Temat niepełnosprawności podjęły z kolei warsztaty zatytułowane Znajdź w sobie Innego (2016). Projekt skierowany był do osób opiekujących się osobami niepełnosprawnymi lub współpracujących z nimi: ich rodziców i opiekunów, pracowników socjalnych, nauczycieli ze szkół lub klas integracyjnych. Podczas licznych warsztatów prowadzonych przez wykwalifikowana kadrę uczestnicy próbowali „dotknąć tego, co jest udziałem ludzi, którzy inaczej widzą, słyszą, poruszają się"27.

27 Zob. http://barakkultury.pl/projekty/ (dostęp: 1.06.2019). 
W 2017 roku Fundacja Barak Kultury zorganizowała dwa wydarzenie o tematyce ekologicznej i no waste: Ekologiczny projekt weekend oraz Piknik Dzień Wiatru. Obydwa przedsięwzięcia adresowane były głównie do rodzin, dzieci i ich opiekunów. Liczne interaktywne warsztaty, jak sadzenie roślin, tworzenie zabawek z materiałów recyklingowych, budowanie gniazd dla pszczół i domków dla owadów, były nie tylko okazją do zabawy, ale także działaniem edukacyjnym z zakresu ekologii, ochrony środowiska, źródeł energii odnawialnej.

Listę zaprezentowanych projektów zamknie najnowsze wydarzenie zainicjowane przez zespół Przemysława Prasnowskiego, zatytułowane Okno na Innych. Przedsięwzięcie - określone przez twórców jako instalacja artystyczno-społeczna - odbywające się od 4 do 6 czerwca 2019 roku, polegało na wystawieniu w witrynie siedziby Baraku Kultury wyjątkowych okazów „Innych”. Nietuzinkowymi eksponatami byli: „Hacen Sahraoui - aktor urodzony we Francji w rodzinie algierskich emigrantów, Agnieszka Sawińska - osoba niewidoma od urodzenia, Bartosz Żurawiecki - krytyk filmowy i zdeklarowany gej oraz Adam Stepnowski-Said - psycholog wspierający dzieci i rodziców będących ofiarami uprzedzeń rasowych, który wystąpi w roli Afro-polaka"28. Poznaniacy mieli okazję przyjrzeć się „Innym”, porozmawiać z nimi, a twórcom Baraku Kultury udało się zainicjować rozmowę na temat inności, mniejszości kulturowych, etnicznych, wszechobecnych stereotypów i uprzedzeń do tego, co odmienne i nie do końca znane.

Współczesny teatr alternatywny, reprezentowany tutaj przez Fundację Barak Kultury, nie jest ruchem, który buntuje się przeciwko teatrowi „pluszowych foteli”, nie jest również teatrem wprost kontestującym ustrój polityczny, tak jak robił to $\mathrm{w}$ minionych dekadach. Jest zjawiskiem artystycznym, ale równocześnie pełni znaczącą funkcję społeczną, która wybrzmiewa najwyraźniej na gruncie działań pozateatralnych. Wśród jego twórców i animatorów osłabła postawa buntu i kontestacji wobec rzeczywistości politycznej na rzecz zaangażowania się w kwestie społeczne. Teatr ten działa na rzecz mniejszości etnicznych, seksualnych, grup wykluczonych: bezdomnych, dotkniętych ubóstwem, niepełnosprawnych czy uzależnionych. Współczesna scena niezależna włącza się w społeczną debatę na temat palących kwestii, takich jak postępująca degradacja środowiska, nadmierny konsumpcjonizm, problem imigrantów. Teatr offowy buntuje się przeciwko społecznej i ekonomicznej nierówności, braku tolerancji, narastającemu rasizmowi i ksenofobi, ruchom nacjonalistycznym. Walczy o bardziej sprawiedliwe i demokratyczne społeczeństwo. Bunt na jego gruncie przybiera jednak postać zdystansowaną i spacyfikowaną. Teatr ten jako zjawisko artystyczne, intelektualne i kulturotwórcze zajmuje się przede wszystkim ochroną wartości humanistycznych oraz tworzeniem alternatywnych sposobów życia społecznego, bez uciekania się do radykalnych rozwiązań. Jego przedstawiciele w centrum swojej misji stawiają chęć niedestrukcyjnej i pozytywnej zmiany

28 Zob. https://gloswielkopolski.pl/barak-kultury-otwiera-okno-na-innych-wyjatkowy-projekt-zespolu-przemka-prasnowskiego/ar/c13-14172871 (dostęp: 7.06.2019). 
pewnych elementów organizacji życia społecznego, angażując się przede wszystkim na rzecz społeczności wykluczonych i lokalnych oraz terenu, który one zamieszkują. Tak jak ich poprzednicy, chcą bowiem nadal „budować nie tylko alternatywny teatr, ale także alternatywny świat’"29.

\section{Aneks}

\section{Rozmowa z Przemysławem Prasnowskim, założycielem Fundacji Barak Kultury ${ }^{30}$}

Magdalena Grenda: Czy współczesny teatr alternatywny jest teatrem protestu, buntu, oporu?

Przemysław Prasnowski: Nie śledzę aż tak głęboko tego, co się dzieje w teatrze alternatywnym, więc trudno mi się wypowiadać. Intuicyjnie mogę powiedzieć, że jest w nas niezgoda na wiele rzeczy dziejących się wokół nas.

M.G.: Z czym się nie zgadzacie, przeciwko czemu się buntujecie?

P.P.: Nie wiem, czy można to nazwać buntowaniem, ale zawsze staraliśmy się być wierni wartościom, które można osadzić w pewnych nurtach kontrkultury. Myślę, że bliższy jest nam ten nurt, który oprotestowuje rzeczywistość poprzez śmiech. W Polsce robiła to Pomarańczowa Alternatywa. A ponieważ zaczynaliśmy w zgrzebnym baraku, to mimo że teraz jesteśmy już w innym miejscu, tamta przestrzeń nas ukształtowała. Stworzyła w nas poczucie wspólnoty z tymi, którzy żyją na marginesie i są w mniejszości. I jeśli przeciw czemuś się buntujemy, to przeciwko wszelkim przejawom dyskryminacji, wywyższania się i lekceważenia odmienności.

M.G.: Jakie są wasze strategie i praktyki oporu?

P.P.: Nigdy nie tworzyliśmy żadnych strategii czy programów. Jest to nam z gruntu obce i mamy do tego duży dystans. Zawsze kierowaliśmy się intuicją i wrażliwością społeczną.

M.G.: Czy szerokie działania pozateatralne BK rzeczywiście mogą poprawić sytuację grup wykluczonych, rozwiązać palące problemy społeczne, zmienić rzeczywistość? P.P.: My swoimi działaniami nie rozwiążemy problemów społecznych. Od systemowego działania są instytucje i to one powinny to robić. My możemy zatroszczyć się o jednostki i to robimy. W naszych inicjatywach biorą udział m.in. niewidoma Agnieszka Sawińska, która prowadzi escape room w ramach Innego Festiwalu, w mo-

29 L. Śliwonik, W poszukiwaniu zagubionego klucza, w: Świat alternatywny. Seminarium w ramach Łódzkich Spotkań Teatralnych, 5-6.12.1998, Łódzki Dom Kultury, Łódź 1999, s. 7.

30 Rozmowa została przeprowadzona (maj 2019 rok) na potrzeby tegoż artykułu. Wywiad jest po autoryzacji. 
nodramie Teatru Ba-Ku Całe życie $w$ dresach gra Justyna Tomczak-Boczko, matka niepełnosprawnego synka, ekipę Antykabaretu Barbarzyńcy PL tworzą imigranci Eva Rufo, Hacen Sahraoui i zdeklarowany gej Bartosz Żurawiecki. To ci ludzie poprzez swoje historie i autentyczność dają poczucie sensu podobnym sobie, ale też reprezentantom większości. A Barak Kultury tworzy dla nich azyl, gdzie mogą czuć się bezpiecznie. Ta wspólnotowość to jeden z najważniejszych naszych drogowskazów!

\section{Bibliografia}

Dworakowska Z., Kontrkulturowe wyjścia z teatru, w: A. Jawłowska, Z. Dworakowska (red.), Wolność w systemie zniewolenia. Rozmowy o polskiej kontrkulturze, Instytut Stosowanych Nauk Społecznych UW, Warszawa 2008.

Gołaczyńska M., Wrocławski teatr niezależny, Wydawnictwo Uniwersytetu Wrocławskiego, Wrocław 2007.

Grenda M., Mistrzowie drugiego planu. Poznański teatr alternatywny po 1989 roku, Wydawnictwo Naukowe WNS UAM, Poznań 2013.

Grenda M., Poznańscy Offeusze. Teatr alternatywny Poznania po 1989 roku jako zjawisko artystyczne, społeczne i kulturotwórcze, Wydawnictwo Naukowe WNS UAM, Poznań 2018.

Grudzińska M., Drewniak Ł., Obywatel Teatr, w: Krakowskie Reminiscencje Teatralne. Trzy dekady teatru, Stowarzyszenie Rotunda, Kraków 2004.

Jawłowska A., Drogi kontrkultury, Państwowy Instytut Wydawniczy, Warszawa 1975.

Kubikowski T., Teatr alternatywny, w: M. Fik (red.), Encyklopedia kultury polskiej XX wieku. Teatr - widowisko, Instytut Kultury Polskiej, Warszawa 2000.

Lizurek J., Przeczuwać bunt, „Nietak!t” 2016, nr 1 (24).

Semil M., Wysińska E., Słownik współczesnego teatru, Wydawnictwa Artystyczne i Filmowe, Warszawa 1980.

Śliwonik L., W poszukiwaniu zagubionego klucza, w: Świat alternatywny. Seminarium w ramach Łódzkich Spotkań Teatralnych, 5-6.12.1998, Łódzki Dom Kultury, Łódź 1999.

\section{Źródła internetowe:}

http://barakkultury.pl/ (dostęp: 1.06.2019).

https://gloswielkopolski.pl/barak-kultury-otwiera-okno-na-innych-wyjatkowy-projekt-zespolu-przemka-prasnowskiego/ar/c13-14172871 (dostęp: 7.06.2019). 